\title{
Estimating predation rates of restocked individuals: The influence of timing- of-release on metapenaeid (shrimp) survival.
}

\author{
Brran Pooh* \\ Centre for Fish and Fisheries Research, School of Veterinary and Life Sciences, Murdoch University, \\ Western Australia, Australia
}

Keywords: Juvenile penaeids, Metapenaeusdalli, Estuarine fish species, High energy

Accepted on April 05, 2020

\section{Commentary}

Post-release mortality is one of the greatest obstacles in many aquaculture based enhancement programs [1-4], and often the downfall of stock enhancement efforts, regardless of great successes in hatchery culture. Predation is widely known to be a major factor in post-release mortality in hatchery-raised juveniles [5,6] accounting for up to $95 \%$ of post-release mortality [7], and can quickly turn stock enhancement into an expensive exercise in making food for predatory species [8].

Juvenile penaeids are particularly susceptible to predation $[9,10]$ with an estimated $25 \%$ of the juvenile prawns in coastal inland waters lost each week, mainly to predation [11]. This high susceptibility could be attributed to their convenient size as a prey item for many coastal and estuarine fish species [12], as well as their relatively high energy content compared to other benthic macroinvertebrates [13].

In this study, we estimated predation rates by fish on hatcheryraised postlarval Western School Prawn (Metapenaeusdalli) to inform the development of effective release protocols (for overview of program, see Tweedley et al. [14] The fish faunal composition of the test release site; a Halophila ovalis seagrass bed in a temperate Western Australian estuary was determined by seine netting in the day and night, before and before and after the release of $\sim 130,000$ postlarval $M$. dalli. Gut content analysis of 16 abundant teleost species, showed that $\mathrm{t}$ while six species consumed $M$. dalli, two species, Ostorhinchus rueppellii (Apogonidae) and Atherinomorus vaigiensis (Atherinidae), were responsible for $\sim 99 \%$ of the predation, and that the total number of postlarval prawns consumed was $288 \%$ greater at night than in the day. This information and that from previous and past fish monitoring programs provides the basis for selecting optimal release sites. Although seagrass beds generally provide shelter as a nursery habitat [15-17], our results show that this is not always the case review by McDevitt-Irwin et al. [18] The current study demonstrates that by implementing a relatively simple and rapidly executable methodology, critical information about potential release sites can be obtained to inform management choices, overcoming this critical step in successful stock enhancement.

In addition, there is value in considering the predator-evasion capacity of the hatchery-raised stock when deciding age/sizeat-release; effectively a trade-off between an early release to reduce hatchery mortality due to various factors; e.g. intraspecific competition, crowding stress, cannibalism, risk of disease [19,20], and sufficient fitness in the wild; having developed the motility to escape predators, such as the tail-flip response in shrimp [21]. There is also great potential for increasing post-release survival by enriching the hatchery environment for postlarval and juveniles before release. . This can increase predator awareness [22] and promote natural feeding abilities [23], leading to greater survival post-release and hence more effective enhancement strategies.

\section{References}

1. Bell JD. Rothlisberg PC, Munro JL, et al. Restocking and stock enhancement of marine invertebrate fisheries. Adv Marine Biol. 2005: 49; 1-374.

2. Lorenzen K. Population dynamics and potential of fisheries stock enhancement: practical theory for assessment and policy analysis. Phil Trans Royal Soc B Biol Sci. 2005: 360: 171.

3. Lorenzen K, Agnalt AL, Blankenship HL, et al. Integrating marine stock enhancement and restocking into the fisheries management toolbox: progress and roadblocks. Revi Fish Sci. 2013; 21: 213-221.

4. Taylor MD, Chick RC, Lorenzen K, et al. Fisheries enhancement and restoration in a changing world. Fish Res. 2017; 186: 407-412.

5. Stein RA, Carline RF, Hayward RS. Largemouth Bass Predation on stocked Tiger Muskellunge. Trans Amer FishSoc. 1981; 110: 604-612.

6. Støttrup JG, Overton JL, Paulsen H, et al.. Rationale for restocking the eastern Baltic cod stock. Rev Fish Sci. 2008; 16: 58-64.

7. Hines A, Johnson EG, Young AC, et al. Release strategies for estuarine species with complex migratory life cycles: stock enhancement of Chesapeake Blue Crabs (Callinectessapidus). Rev Fish Sci. 2008; 16: 175-185.

8. Loneragan NR, Tweedley JR, Taylor MD. A drop in the ocean: marine releases in Australia. Austral Ecology. 2017.

9. Minello TJ. Zimmerman RJ. Fish predation on juvenile brown shrimp, Penaeusaztecus Ives: The effect of simulated Spartina structure on predation rates. J Exp Marine Biol Ecol. 1983; 72: 211-231.

10. Haywood MD, Heales DS, Kenyon RA, et al. Predation of juvenile tiger prawns in a tropical Australian estuary. Marine EcolProg Ser.1998; 162: 201-214.

11. Dall W, Hill BJ, Rothlisberg PC, et al. The biology of the penaeidae. Adv Marine Biol. 1990; 27: 1-489. 
Citation: Brian Poh. Estimating predation rates of restocked individuals: The influence of timing-of-release on metapenaeid (shrimp) survival.

12. Salini JP, Blaber SJM, Brewer DT. Diets of piscivorous fishes in a tropical Australian estuary, with special reference to predation on penaeid prawns. Marine Biol. 1990; 105: 363-374.

13. Thayer GW, Schaaf WE, Angelovic JW, et al. Caloric measurements of some estuarine organisms. Fish Bullet. 1973; 71: 289-296.

14. Tweedley JR, Loneragan NR, Crisp JA, et al. Stock enhancement of the Western School Prawn (Metapenaeusdalli) in the Swan-Canning Estuary; evaluating recruitment limitation, environment and release strategies. RepFishResDevCorp. 2018; 546.

15. Loneragan NR, Heales DS, Haywood MDE, et al. Estimating the carrying capacity of seagrass for juvenile tiger prawns (Penaeussemisulcatus): enclosure experiments in high and low biomass seagrass beds. Marine Biol. 2001; 139: 343-354.

16. Loneragan NR, Kenyon RA, Haywood MDE, et al. Impact of cyclones and macrophytes on the recruitment and landings of tiger prawns, Penaeusesculentus, in Exmouth Gulf Western Australia. Est Coastal Shelf Sci. 2013; 127: 46-58.

17. Lefcheck JS, Hughes BB, Johnson AJ, et al. Are coastal habitats important nurseries? A meta - analysis. Cons Lett. 2019; e12645.

18. McDevitt-Irwin JM, Iacarella JC, Baum JK. Reassessing the nursery role of seagrass habitats from temperate to tropical regions: a meta-analysis. Mar EcolProg Ser. 2016; 557: 133-143.

19. Kolkovski S, King J, Watts N, et al. Development of octopus aquaculture Final Report. FRDC Project No. 2009/206. Fish ResRep. 2009; 262: 144.
20. Spitznagel MI, Small HJ, LivelyJA, et al. Investigating risk factors for mortality and reovirus infection in aquaculture production of soft-shell blue crabs (Callinectessapidus). Aquacul. 2019; 502: 289-295.

21. Arnott SA, Neil D, Ansell AD. Escape trajectories of the brown shrimp Crangoncrangon, and a theoretical consideration of initial escape angles from predators. J Exp Biol. 1999; 202: 193-209.

22. Jackson CD, Brown GE. Differences in antipredatorbehaviour between wild and hatchery-reared juvenile Atlantic salmon (Salmosalar) under seminatural conditions. Canadian J Fish Aquat Sci. 2011; 68 (12): 2157-2166.

23. Cámara-Ruiz M, Santo CS, Gessner J, et al. How to improve foraging efficiency for restocking measures of juvenile Baltic sturgeon (Acipenseroxyrinchus). Aquacul. $2019 ; 502 ; 12-17$.

\section{*Correspondence to}

Brian Poh

Centre for Fish and Fisheries Research

School of Veterinary and Life Sciences

Murdoch University

Western Australia, Australia

E-mail: poh.brian@gmail.com 